\title{
Research and adoption of biotechnology strategies could improve California fruit and nut crops
}

\author{
by Victor M. Haroldsen, Gabriel Paulino, Cecilia \\ L. Chi-Ham and Alan B. Bennett
}

\section{California's fruit and nut tree crops rep-} resent one-third of the state's cash farm receipts and $70 \%$ of U.S. fruit and nut production. Advances in crop biotechnology and genetic engineering could help protect these valuable crops from pests and diseases and improve productivity. However, due to the difficulty of genetically engineering woody tree crops, as well as intellectual property concerns, regulatory hurdles and public perceptions about genetic engineering, biotechnology has not gained a foothold in this area of agriculture. Our survey of published genetic engineering research and issued field trial permits between 2000 and 2011 revealed that citrus and grape are the focus of most current work, and that walnut - not the more widely planted almond - is the focus among nut crops. Matching publicly funded genetic engineering research projects to a survey of the industry's top needs, we found that far less than half of the funded research has focused on the top-identified pest and disease threats. The most promising genetic engineering technology for fruit and nut tree crops may be transgrafting, which could address consumer concerns and benefit growers.

B iotechnology is a unique avenue for incorporating innovations into crop plants. In general, growers have a vested interest in adopting technologies that can raise crop yields by reducing disease pressure or improving growth conditions, yet growers remain skeptical of genetic engineering innovations due to the uncertainty of consumer and market acceptance (Mulvaney et al. 2011). On a global scale,

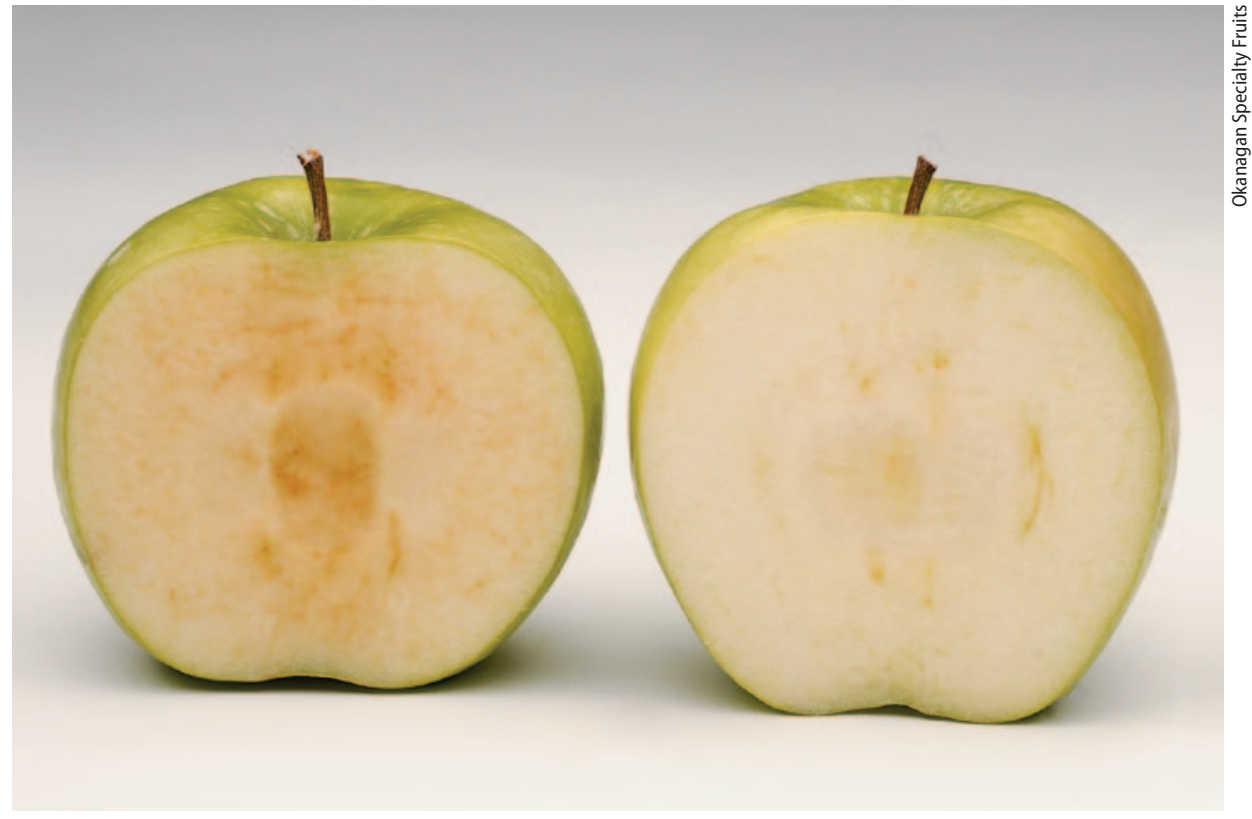

Genetically engineered field crops such as corn and soybeans are widely planted in the United States, but few fruits or nuts have been commercialized. Okanagan Specialty Fruits of Canada is seeking regulatory approval for its genetically engineered Arctic apple (right). This apple's browning genes were replaced with nonbrowning apple genes that produce too little polyphenol oxidase to trigger browning (left). The nonbrowning trait can be introduced into any apple variety.

however, transgenic crops are making an impact: in 2010, transgenic crops contributed an estimated $\$ 10.7$ billion in direct global farm income, while providing a reduction of 86.2 million pounds $(10.2 \%)$ of pesticide usage and proffering an associated $21.8 \%$ reduction in the environmental impact quotient, a "field value per hectare" metric that takes into account toxicity and environmental exposure data related to individual pesticides (James 2010).

Currently marketed genetically engineered crops mainly consist of large-acreage row crops such as cotton, soybean, corn and canola. To date, genetically engineered fruit and nut trees include only virus-resistant papaya (Carica papaya), which significantly benefited the Hawaiian industry (Gonsalves 2004), and a more recently approved, but not yet commercialized, plum pox virus-resistant plum (Prunus domestica). The challenge remains to extend the benefits that biotechnology can deliver to a broader range of agriculturally important crops.

According to the U.S. Department of Agriculture's (USDA) Economic Research Service, California was the number one exporter of agricultural commodities in the United States in 2010; the state's total cash farm receipts, including exports, were $\$ 37.6$ billion, of which one-third were fruits and nuts (USDA ERS 2011). In 2010, California contributed over $\$ 13.2$ billion to the total $\$ 20.9$ billion U.S. fruit and nut market (USDA NASS 2011).

In agriculture, biotechnology involves the insertion of one or more specific genes into a plant to impart a new characteristic or trait. These new traits can endow the modified plant with better resistance to insects, herbicides, disease or environmental stressors such as drought. An example of one of the most widespread applications of agricultural biotechnology is the use of glyphosate-tolerant (Roundup Ready) soybeans.

Often cited as the "birthplace of biotechnology," California has remained relatively open to biotechnology and genetic engineering innovations in agriculture. Since 2000, the USDA Animal and Plant Health Inspection Service has issued

Online: http://californiaagriculture.ucanr.edu/ landingpage.cfm?article=ca.v066n02p62\&fulltext=yes DOI: 10.3733/ca.v066n02p62 
more than 1,100 environmental release or interstate movement permits for genetically engineered crops in California, more than twice the number issued in any other U.S. state (USDA APHIS 2011).

In a state where agriculture plays such an important role in the economy and where the biotechnology industry has such a strong presence, we sought to determine the status of biotechnology applications in a subset of California specialty crops: the top 10 woody fruit and nut crops, by production value. To gain a general overview of this status, we first examined the number of peerreviewed publications that described genetic engineering technologies among these crops. Next, to assess the research priorities supported by industry, we surveyed individual fruit and nut crop advisory boards, obtained input from UC Cooperative Extension advisors and the UC Fruit and Nut Research and Information Center, as well as the UC Statewide Integrated Pest Management (IPM) Program website. This information allowed us to assess the most pressing pest- and disease-related issues for these crops. We then examined which issues were being addressed using biotechnology by assessing the number of related scientific publications and genetic engineering field permits for each fruit and nut crop. Lastly, we looked at the concept of transgrafting fruit and nut trees on to genetically engineered rootstock, how this could benefit growers, and the regulatory hurdles this technology may face.

\section{Top 10 fruit and nut crops}

California's fruit and nut tree crops consist of 35 species, ranging from almond to walnut and including a number of berries (USDA NASS 2011). We analyzed and ranked these crops in terms of value. Excluding strawberry (Fragaria $x$ ananassa), the top 10 woody fruit and nut crops had a cumulative production value of $\$ 10.86$ billion in California, representing $77 \%$ of total U.S. production (fig. 1).

In 2010, California produced 14.8 million tons (13.4 million metric tons) of fruits and nuts, $60 \%$ of the U.S. utilized production (the amount of a farm's crop that is sold), with citrus (Citrus spp.) and grape (Vitis vinifera) comprising the majority of this amount (fig. 2, table 1). California was a major producer of almond (Prunus dulcis), walnut (Juglans regia), pistachio (Pistacia vera), avocado (Persea americana), plum (Prunus domestica), peach (Prunus persica) and grape, accounting for $76 \%$ to $100 \%$ of all U.S. production for each (fig. 2, table 1). California citrus accounted for one-third of U.S. production volume and $44 \%$ of total U.S. production value at $\$ 1.3$ billion in 2010 (fig. 1). Additionally, 9\% of the total top 10 U.S. fruit and nut products was exported in $2010,60 \%$ of which were produced in California. Almond, walnut and pistachio contributed most to total U.S. export value, tallying $\$ 3.24$ billion of $\$ 3.78$ billion in exports in 2010 (USDA ERS 2011).

Improved crop management and agronomic practices have helped attain high levels of productivity for major crops such as wheat, rice and maize (Oerke and Dehne 2004). Crop protection has also played an integral role in maintaining productivity in the face of challenges by viruses, bacteria and fungi. The use of biotechnology in protecting crops from disease and pests promises even greater potential for productivity. Implementing

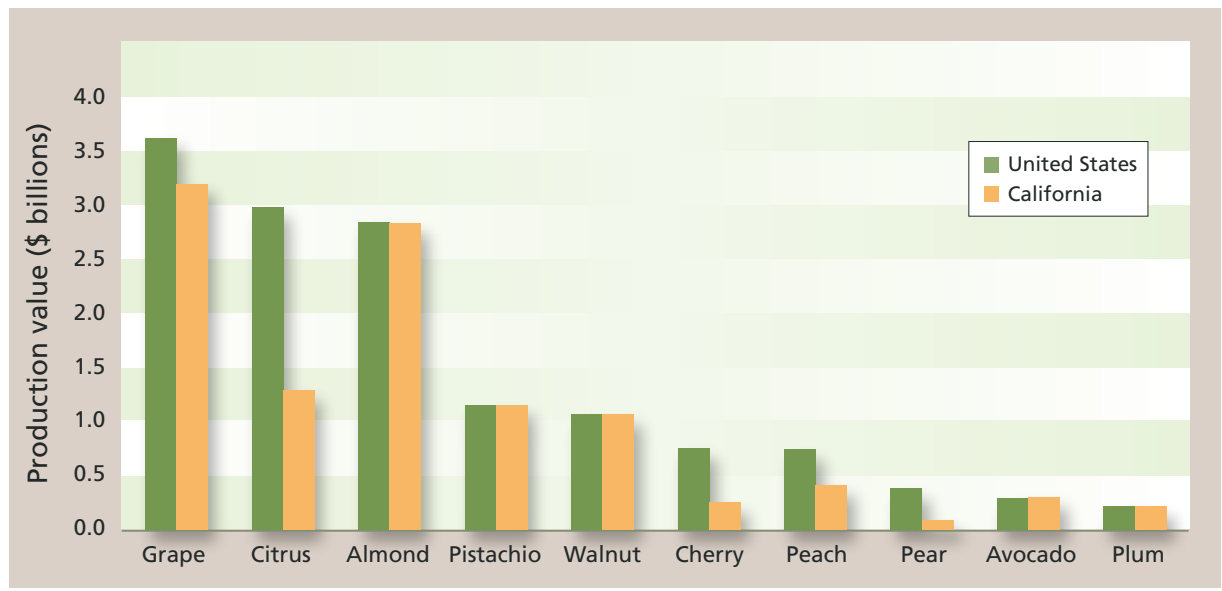

Fig. 1. Production value of top 10 woody fruit and nut tree crops in the United States and California, 2010. Crops are ranked in descending order of U.S. production value.

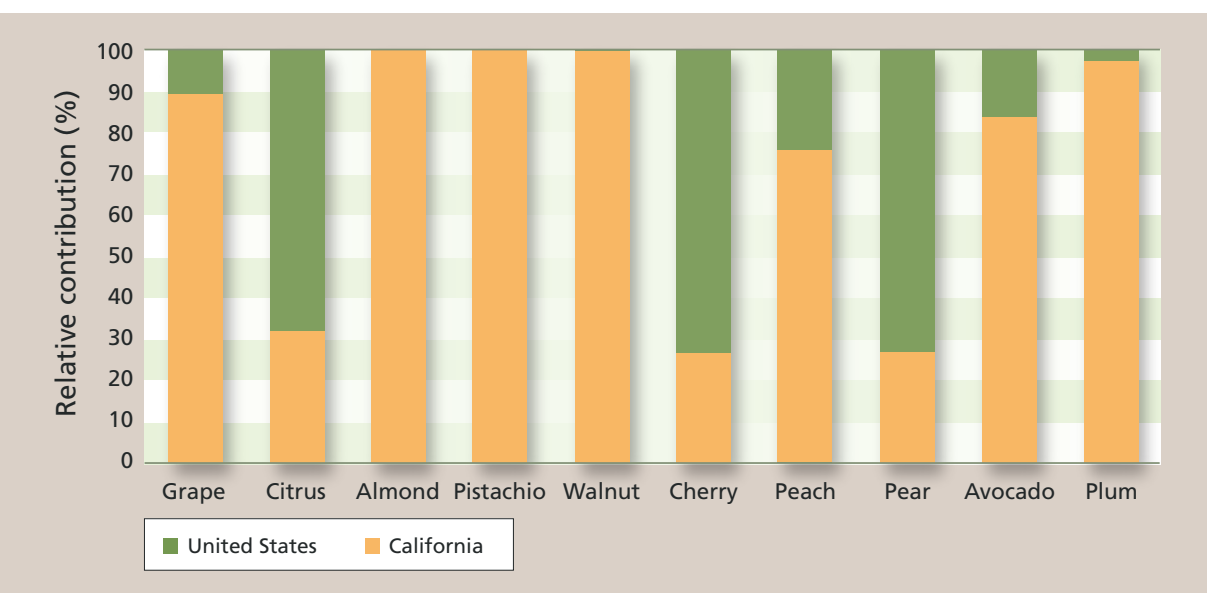

Fig. 2. Relative contribution of California production to total U.S. production of top 10 woody fruit and nut crops, 2010. Crops are listed left to right in descending order of U.S. production value.

TABLE 1. Export tonnage and value for top 10 California woody fruit and nut crops, 2010

\begin{tabular}{|c|c|c|c|c|c|c|c|c|c|c|}
\hline & Grape* & Citrus & Almond & Pistachio & Walnut & Cherry & Peach & Pear & Avocado & Plum \\
\hline $\begin{array}{l}\text { U.S. } \\
\text { production } \\
\text { (1,000 tons) }\end{array}$ & 7,412 & 11,734 & 1,414 & 261 & 503 & 348 & 1,364 & 814 & 149 & 531 \\
\hline Exported (\%) & $<1$ & 10 & 71 & 66 & 43 & 17 & 4 & 1 & 14 & 13 \\
\hline $\begin{array}{l}\text { Export value } \\
\text { (\$ millions) }\end{array}$ & 11.7 & 293.1 & $2,021.8$ & 766.9 & 453.2 & 129.9 & 30.8 & 2.7 & 43.9 & 30.0 \\
\hline
\end{tabular}

* Crops listed left to right in descending order of U.S. production value. 
biotechnology strategies might help growers realize substantial yield gains similar to those that have been documented for other genetically engineered crops during the last decade (James 2010). Underscoring the significance of this potential, in 2009, $75 \%$ of the $\$ 10.7$ billion in estimated economic benefits from genetically engineered soy, maize, cotton and canola were due to yield gains alone (James 2010). It remains to be seen what sorts of yield gains would be possible for genetically engineered fruits and nuts.

\section{Survey of public research}

Using keyword searching in ISI Web of Knowledge and OvidSP CAB Abstracts databases, over 4,400 international, English-language, scientific publication entries were obtained, and 139 of these were compiled and reviewed in detail.

The scientific publications that we examined described genetic engineering strategies related to improving general agronomic properties such as drought, salinity or temperature tolerance; the modification of flowering time or plant architecture; herbicide resistance; product quality traits; and bacterial, fungal, insect and viral resistance. We examined only strategies demonstrating potentially useful applications for the fruit and nut industry; we did not consider publications that solely addressed genetic engineering methods or involved genes unrelated to agricultural productivity.

The number of permits giving permission to field-test noncommercial, genetically engineered plants was obtained from various USDA agencies from 2000 to 2011. We recognize that given the long time frames for developing and deregulating transgenic fruit and nut trees (transgenic plum has taken nearly 20 years, for example), field permits for research are frequently renewed and often overlap. The way in which field permit data is submitted makes it extremely difficult to follow the process of a single transgenic crop that is being developed, so we cannot be certain of the extent of this overlap. However, the continual renewal of permits indicates, at the very least, that research on specific crops continues to move through the regulatory chain.

Our survey showed that research publications and field permits related to genetic engineering were concentrated in the highest-value crops, except for

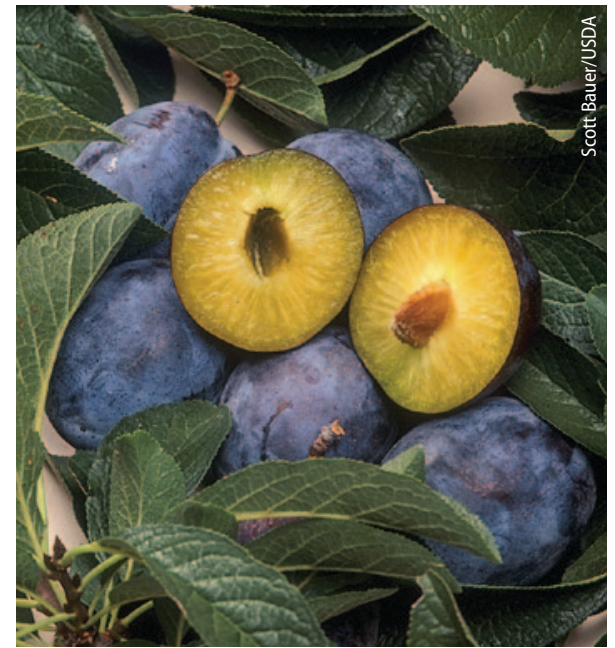

and the European Union will not import genetically engineered crop products. Interestingly, $43 \%$ of U.S. walnuts were exported last year and walnuts ranked third in overall export value, yet this sector is taking the lead within the nut tree industry, with several genetic engineering publications and field permits.

Both citrus and grape had a similar total number of field permits plus publications - the top two in this study. However, grape genetic engineering research had nearly twice as many field permits as publications, while citrus had only one-third as many field permits as publications. This suggests that grape research has been more effectively translated from the laboratory to the field. This may be due, at least in part, to support for the grape industry to find innovative solutions to potentially devastating diseases. In recent meetings of the Pierce's Disease Board, the magnitude and significance of Pierce's disease to the California grape and wine industry were central to discussions, and research results that directly addressed combating Pierce's disease were underscored as vitally important (CDFA 2007). Industry encouragement and incentives may be paramount to ensuring that research enters the translational pipeline to field evaluation and ultimately to commercial implementation.

\section{Industry needs and public research}

Economic losses due to pests and diseases in fruit and nut tree crops are not reported consistently on an annual basis. However, based on the results from other major crops, losses may approach $32 \%$, with potential losses as high as $67 \%$ if integrated pest management practices are Major trading partners such as Japan

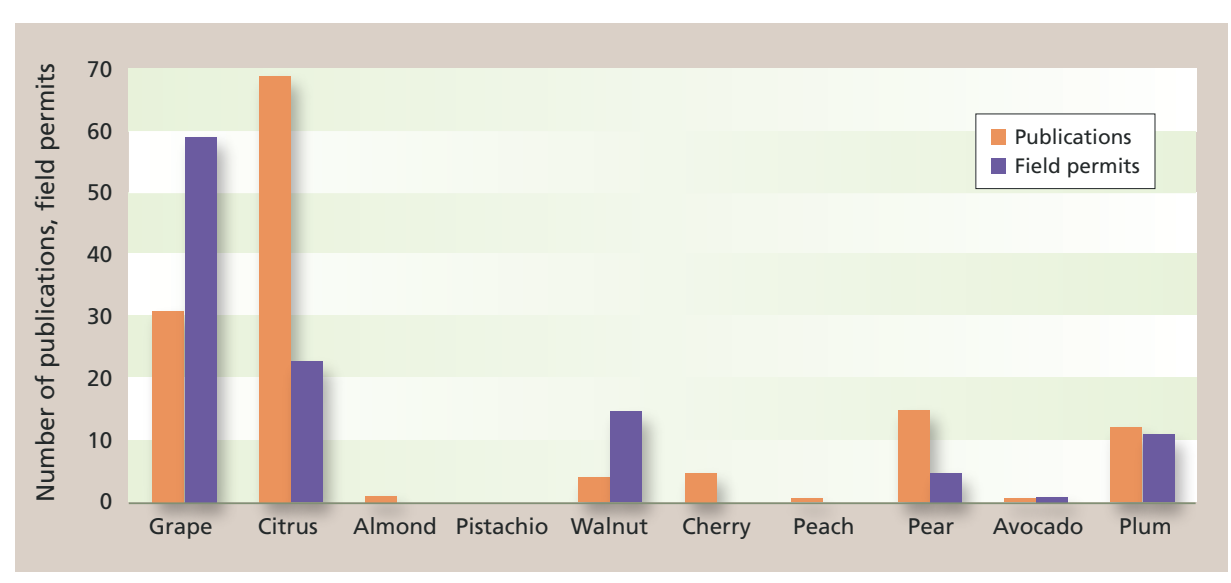

Fig. 3. Number of scientific publications and field permits in public databases for genetically engineered fruit and nut crops, 2000-2011. Crops are shown left to right in descending order of U.S. production value. 
not used (Oerke and Dehne 2004). Under a worst-case scenario, this represents a potential $\$ 3.5$ billion to $\$ 7.3$ billion loss for California's fruit and nut sector. With such a large fraction of California's agricultural economy dependent on consistent yields of these crops, pest- and diseaserelated losses directly affect the financial viability of the state's agricultural sector.

Since public-private partnerships are intrinsic to California agriculture, we investigated if industry pest and disease priorities were aligned with genetic engineering research being performed at public institutions. Through personal communications with fruit and nut advisory boards and UC Cooperative Extension advisors, we identified the most pressing pest- and disease-related issues that threaten California fruit and nut crops (table 2). Additionally, we reexamined the 139 scientific publications previously mentioned and assigned them to research categories.

Our results indicated that most genetic engineering research in fruit and nut trees was focused on pest- and diseaserelated issues (fig. 4), with the other major focus on agronomic properties, such as early-flowering phenotype or salinity tolerance. Surprisingly, only $5 \%$ of genetic engineering research was devoted specifically to insect resistance. In contrast, researchers working on major row crops such as cotton and maize tend to use insect-resistance traits - such as technologies based on Bt (Bacillus thurengiensis) as a significant portion of their genetic engineering portfolio.
The two crops with the greatest amount of research, citrus and grape, had 62 pest- or disease-related publications describing genetic engineering strategies (figs. 5A and 5B, table 2). Publications were classified as disease and pest related if the genetically engineered trait targeted a fungus, bacteria, insect or virus. The publications data column in table 2 shows the number of peer-reviewed publications that describe genetic engineering strategies for a crop's top-identified diseases and pests; the second column shows the number of publications describing genetic engineering strategies for all diseases and pests, not just the top-identified problems. For example, citrus had 42 publications that used genetic engineering to target a pest or disease, but only 13 of those were directed toward citrus canker, one of its top-identified diseases.

The grape and citrus industries have identified the most critical pests and diseases to bring under control. Citrus greening, or huanglongbing (HLB), is high on the list. It is one of the most serious disease threats in citrus to emerge in recent years, with no known effective control other than to remove infected trees. Although it is not known to have entered California, HLB is present in several southeastern states, and strict quarantine controls are currently the

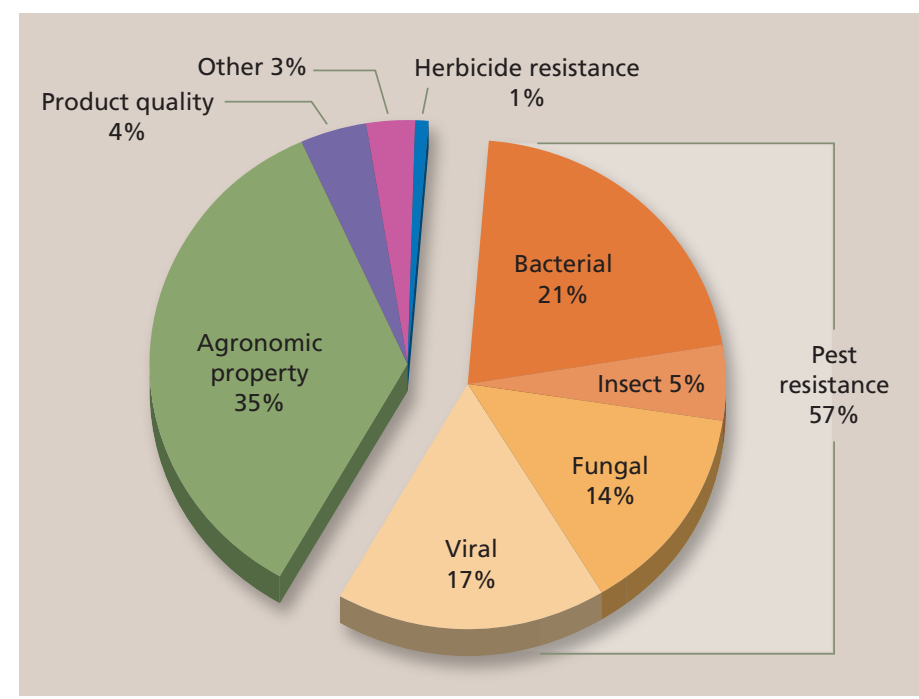

Fig. 4. Categories of genetic engineering research found in publications for the top 10 woody fruit and nut crops $(n=139)$.

only way to keep it at bay (USDA APHIS 2010). With such a devastating disease looming, the need to find and implement solutions, whether conventional or biotechnology-based, cannot be overstated.

Comparing pest and disease concerns identified by industry members to published research topics, we found that far less than half of the published genetic engineering research has focused on the top-identified threats (table 2).

Recognizing the time frames involved in fruit tree research, it is possible that ongoing research simply has not been published yet. If industry needs and public research efforts are aligned, we would expect that after a lag period, genetic engineering research related to many of these pests and diseases will be published in the near future. Citrus and grape may have the highest number of pest and disease issues being addressed because of the involvement of commodity funding organizations such as the Citrus Research and Development Foundation and the Pierce's Disease/Glassy-winged Sharpshooter Board. Interactions between

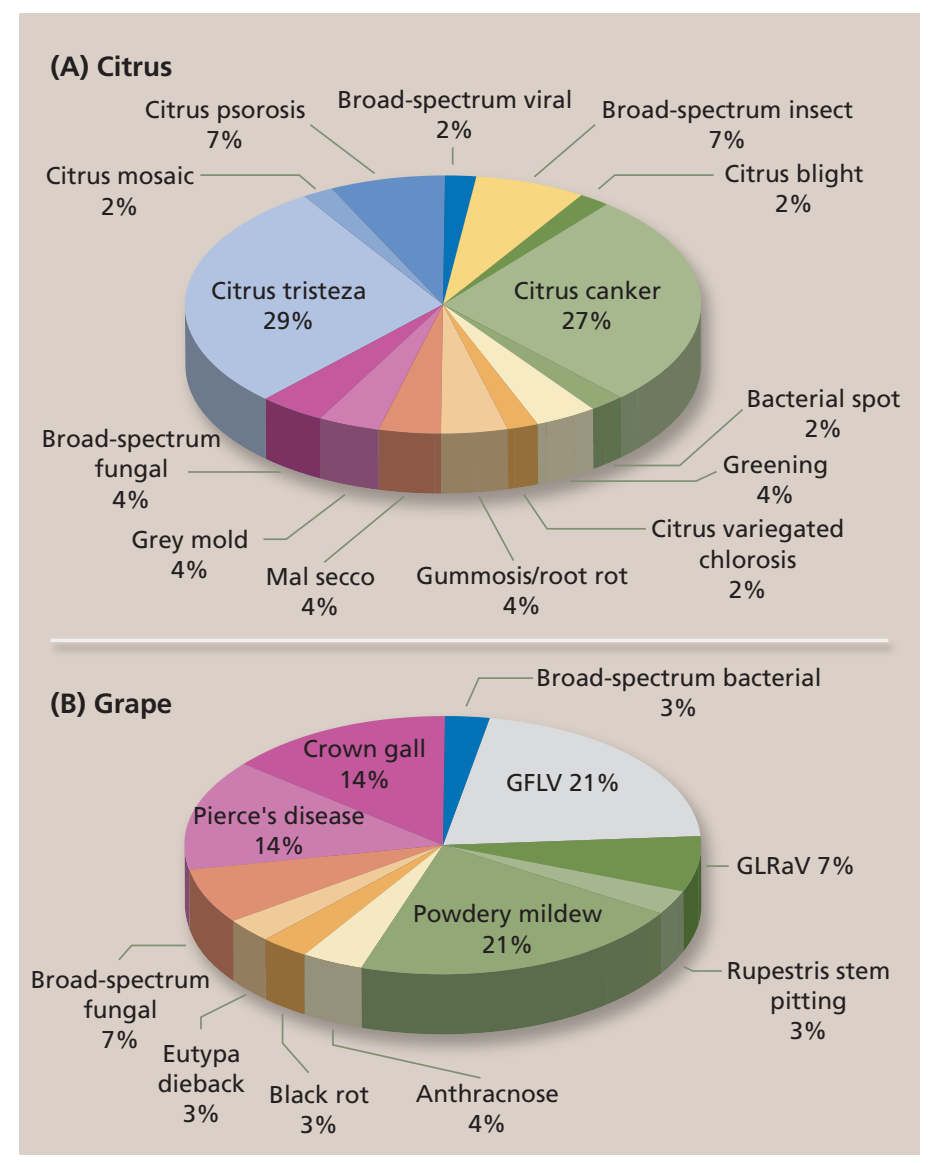

Fig. 5. Detailed analysis of research in genetic engineering-based publications on (A) citrus $(n=42)$ and (B) grape $(n=20)$. 
TABLE 2. Top-identified pests and diseases of top 10 California woody fruit and nut crops, and related genetic engineering (GE) publications, 2000-2011

\begin{tabular}{|c|c|c|c|}
\hline \multirow[b]{2}{*}{ Crop* } & \multirow[b]{2}{*}{ Diseaset } & \multicolumn{2}{|c|}{ GE-based publications } \\
\hline & & On diseaseł & $\begin{array}{l}\text { Generally pest } \\
\text { related§ }\end{array}$ \\
\hline \multirow[t]{5}{*}{ Grape } & Powdery mildew & 6 & 20 \\
\hline & Pierce's disease & 4 & \\
\hline & Eutypa dieback & 1 & \\
\hline & Mealybug & 0 & \\
\hline & Nematode & 0 & \\
\hline \multirow[t]{5}{*}{ Citrus } & Canker & 13 & 42 \\
\hline & Greening (HLB) & 2 & \\
\hline & Phytophthora root rot & 2 & \\
\hline & Asian citrus psyllid & 0 & \\
\hline & Thrips & 0 & \\
\hline \multirow[t]{5}{*}{ Almond } & Anthracnose & 0 & 1 \\
\hline & Brown rot & 0 & \\
\hline & Rust & 0 & \\
\hline & Scab & 0 & \\
\hline & Shot hole & 0 & \\
\hline \multirow[t]{3}{*}{ Pistachio } & Alternaria late blight & 0 & 0 \\
\hline & B. panicle/shoot blight & 0 & \\
\hline & Verticillium wilt & 0 & \\
\hline \multirow[t]{4}{*}{ Walnut } & Crown gall & 1 & 2 \\
\hline & Blackline & 0 & \\
\hline & Walnut blight & 0 & \\
\hline & Phytophthora crown/root rot & 0 & \\
\hline \multirow[t]{3}{*}{ Cherry } & Canker & 1 & 2 \\
\hline & Fruit rot & 0 & \\
\hline & Powdery mildew & 0 & \\
\hline \multirow[t]{5}{*}{ Peach } & Brown rot & 0 & 0 \\
\hline & Leaf curl & 0 & \\
\hline & Peach twig borer & 0 & \\
\hline & Rust & 0 & \\
\hline & Sour rot & 0 & \\
\hline \multirow[t]{5}{*}{ Pear } & Fireblight & 6 & 8 \\
\hline & Codling moth & 0 & \\
\hline & Mites & 0 & \\
\hline & Root rot & 0 & \\
\hline & Scab & 0 & \\
\hline \multirow[t]{5}{*}{ Avocado } & Amored scales & 0 & 1 \\
\hline & Dothiorella complex & 0 & \\
\hline & Phytophthora & 0 & \\
\hline & Thrips & 0 & \\
\hline & Mites & 0 & \\
\hline \multirow[t]{4}{*}{ Plum } & Brown rot & 0 & 9 \\
\hline & Omnivorous leafroller & 0 & \\
\hline & P. syringae & 0 & \\
\hline & Oriental fruit moth & 0 & \\
\hline
\end{tabular}

\footnotetext{
* In descending order of U.S. production value.

† Based on information provided by fruit/nut advisory boards, UC Cooperative Extension advisors and the UC Fruit and Nut Research and Information Center.

₹ Genetic engineering-related publications addressing that specific disease or pest.

$\S$ All genetic engineering-related publications for pests and diseases of that crop.
}

the private and public sectors appear to be important in aligning scientific and industry research priorities.

\section{Transgrafting fruit trees}

Given the severity of diseases such as HLB that have no known conventional controls, it is imperative to consider alternative methods to assist in crop protection. The concept of transgrafting - a blend of a common agronomic technique and modern biotechnology - was introduced nearly a decade ago. Transgrafting is the grafting of a transgenic rootstock with a conventional wild-type scion; it introduces genetic engineering innovations into commercial settings while maintaining a non-genetically engineered fruit or nut (Escobar et al. 2001; LevYadun and Sederoff 2001). Transgrafting allows industry to benefit from transgenic traits while potentially mitigating consumer concerns about genetically engineered crops. Regulatory and consumer concerns over the flow of genetically engineered pollen may also be decreased in properly maintained transgrafted orchards, since it is the wild-type scion, not the genetically engineered rootstock, that flowers and produces pollen (COGEM 2006; Lev-Yadun and Sederoff 2001).

From an industry or commercialization perspective, achieving regulatory approval of a single rootstock is preferable to seeking approval for multiple scion cultivars, given the estimated regulatory cost of $\$ 7$ million to $\$ 15$ million for each approval process (Kalaitzandonakes et al. 2006). A single, approved, genetically engineered rootstock could be used with several different scion cultivars, including scions that are resistant to genetic engineering and in certain cases scions from other species (for example, an almond scion might be grafted onto a plum rootstock).

Transgrafting applications that are moving toward commercialization include a crown gall-resistant walnut rootstock (see photo, page 67) (Escobar et al. 2002) and a grape rootstock that produces pear polygalacturonase-inhibiting protein (Aguero et al. 2005), which confers a moderate level of resistance to Pierce's disease. These applications address root or xylem pests and diseases, but future applications will likely target traits aimed at consumer needs such as increased nutritional value or improved flavor characteristics.

Public-private partnerships will be critical to moving promising technologies such as transgrafting into the market, especially because in comparison to row crops, fruits and nuts are minor-acreage specialty crops, making them less attractive to private investment. Nearly all fruit and nut trees grown on a commercial scale are currently grafted, so using genetically engineered rootstocks is technically feasible for this industry.

\section{Intellectual property strategies}

The regulatory status of transgrafted crops is unclear (see sidebar, page 68), necessitating innovative research and development strategies. Transitioning biotechnology from publicly funded research and development to commercial applications will require an intellectual property strategy to access and protect agricultural innovations (Mou and Scorza 2010). Perhaps to the advantage of fruit and nut tree crops, public institutions have been more involved in transgenic research of specialty crops than of commodity crops such as maize or soy, which could facilitate the process, since intellectual property and 
innovations have traditionally been shared more readily between public institutions (Graff et al. 2004).

In the past decade, several public-sector initiatives have been launched to support the development of new biotechnology crops. For example, PIPRA, a nonprofit organization, was established at UC Davis by the Rockefeller and McKnight foundations to facilitate access to patented and proprietary technologies for the development and commercialization of agricultural crops, primarily in developing countries, but also for public entities (Atkinson et al. 2003). The USDA APHIS Biotechnology Quality Management System was established in 2007 to help technology developers with the tools needed for regulatory compliance and to facilitate regulatory clearances.

\section{Public perception}

Strategies based on biotechnology or genetic engineering have the potential to address many of the pest and disease problems in fruit and nut tree crops, but consumer and export-market resistance have hampered their progression and implementation (Mou and Scorza 2010). If perceived risks to personal health and the environment could be reduced, or if the benefits of biotechnology and genetic engineering were targeted to consumers (second-generation traits, such as better tasting or more nutritious fruits) instead of farmers (first-generation traits, such as herbicide- or drought-tolerant crops), there is a greater possibility that consumers would accept fresh genetically engineered products (Astrid 2009; Huffman and Rousu 2006; Lusk et al. 2004). Only $4 \%$ of the genetic engineering research on fruit and nut trees that we surveyed was directed toward product quality (fig. 4), including producing taste-modifying proteins, modifying juice quality, decreasing seed set and producing anthocyanin, an antioxidant. One of the first genetically engineered fruit products aimed at consumers instead of producers is a nonbrowning apple developed in Canada that will

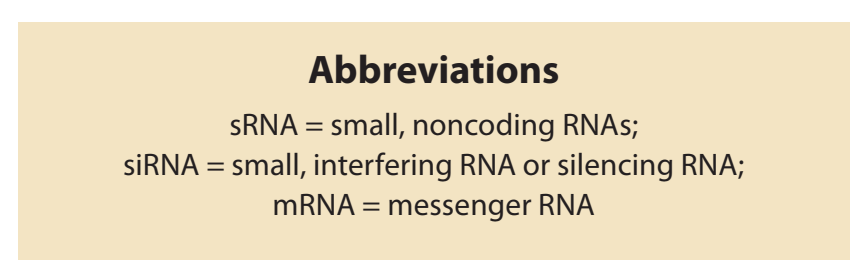

a scion free of transgenic DNA, but the scion would have received translocated transgenic products such as insecticidal proteins or siRNAs to combat certain bacterial or viral diseases. Or its secondgeneration genetic engineering traits could modulate scion or fruit development or influence its organoleptic properties, such as flavor, scent, texture or color.
We expect that because of their ability to transport transgenic products to wild-type scions, second-generation transgrafts would likely receive regulatory scrutiny similar to that of current genetic engineering applications. However, if second-generation traits are incorporated into transgrafted crops, consumers may re-evaluate the perceived risk/ benefit relationship that these products can offer (Astrid 2009; Huffman and Rousu 2006). Since transgrafted crop scions are free of transgenic DNA, and consumers are less resistant toward second-generation traits from genetically engineered crops (Bernard et al. 2009), it is likely possible that second-generation transgrafted products would have a better chance of being marketable relative to their "traditional" genetically engineered counterparts.

\section{Looking forward}

Fruit and nut tree crops are a multibillion-dollar industry in California, and if current trends persist, the industry will continue to grow. Land-grant universities with agricultural roles, such as UC Berkeley, UC Davis and UC Riverside, have a general mission to give back to society by identifying and addressing the agricultural, environmental and ecological needs of industry, government agencies and the community - not only on a local level, but globally as well. As the industry grows, new threats to agriculture, as well as solutions, will emerge. We anticipate that genetic engineering technologies will be a part of that future, but progress has been slow. Given the estimated cost to deregulate a genetically engineered crop variety, it comes as no surprise that the majority of crops that have moved forward are high-value commodities. Furthermore, since specialty crops such as grape and citrus do not need to be replanted every year like maize and soybean, collecting ongoing revenue from seed sales would be less lucrative.

A recent broad survey of all genetically engineered specialty crops found that adjustments to current regulatory 


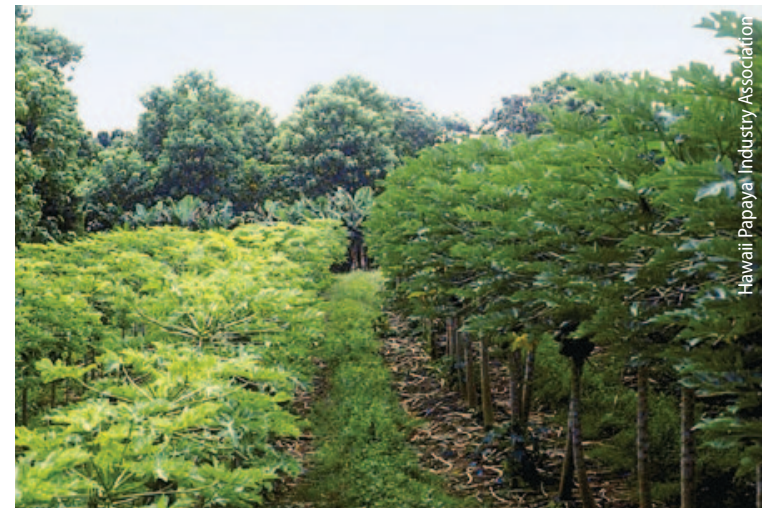

In Hawaii, papaya has been genetically engineered to resist ringspot virus: infected plants on (left), virus-resistant (right).
While the lengthy regulatory approval process may account for some of these delays and market failures, public approval and consumer and export-market acceptance will remain the ultimate hurdles in the marketplace success of genetically engineered specialty crops (Astrid 2009; Huffman and Rousu 2006; Lusk et al. 2004). The degree of market acceptance varies, with some markets being more affected than others by international

requirements might be necessary if commercialization of these crops is to become a reality (Miller and Bradford 2010; Mou and Scorza 2010). In the survey, conducted between 2005 and 2008, research publications identified 78 different specialty crops and more than 250 traits; however, none of the crops had received complete regulatory approval or been commercialized (Miller and Bradford 2010). attitudes about genetic engineering.

Transgrafting presents a potential way to address consumer acceptance issues and allow the fruit and nut tree industries to realize some of the possible benefits of genetic engineering technology. To move transgrafting technologies toward implementation efficiently and effectively, scientists and legislators must establish clear lines of communication and create supportive regulatory frameworks. Moreover, industry backing will be paramount given the long time frames and costs related to genetic engineering. Ultimately, however, consumer education and attitudes toward transgrafting will be a pivotal aspect. It is important that all of these factors are addressed if specialty crops, such as fruit and nut trees, are to profit from the benefits biotechnology can provide.

\begin{abstract}
V.M. Haroldsen is Scientific Analyst, Morrison and Foerster, San Francisco; G. Paulino is Manager of Business Development, SPRIM, San Francisco; C.L. Chi-Ham is Director of Biotechnology Resources, PIPRA, Davis; and A.B. Bennett is Professor, Department of Plant Sciences, UC Davis, and Executive Director, PIPRA.

A Plant Sciences Departmental GSR award and the Rockefeller Foundation supported work performed at UC Davis. Specific information on individual fruit and nut crops is available from the authors upon request.
\end{abstract}

\section{Regulatory status of transgrafted plants is unclear}

\author{
by Victor M. Haroldsen, Gabriel Paulino, Cecilia L. Chi-Ham and \\ Alan B. Bennett
}

\begin{abstract}
$\neg$ he regulatory implications of using transgrafted plants 1 are currently unknown. A plant's vascular system can selectively transport across graft junctions endogenous elements such as full-length RNAs, sRNAs, proteins, hormones, metabolites and vitamins, and even elicit epigenetic effects, heritably changing the way genes are expressed without changing the actual DNA sequence. However, not all of these elements are transported freely, and they either require specific molecular signals or cellular transporters to aid in their movement through a plant's vascular system.

These transfers are understood to a degree (Haroldsen et al. 2012), but what is less clear is how the movement of these elements from transgenic rootstocks to scions might affect the regulatory approval process for a transgrafted plant - a product developed using transgenic tools and yet not containing transgenic DNA in the scion product. It cannot be said with certainty if transgenic RNAs, sRNAs or proteins produced in rootstocks may make their way to the nontransgenic scion. Furthermore, some of these elements may have short half-lives, making it difficult to determine by testing whether the final crop was produced using a transgraft.

There is no precedent within the regulatory framework coordinated by the U.S. Department of Agriculture, U.S. Food and Drug Administration and U.S. Environmental
\end{abstract}

Protection Agency regarding how a transgrafted, genetically engineered rootstock and wild-type scion might be regulated. U.S. regulation identifies genetically engineered crops through a product-based policy; that is, if the final product contains transgenic material, then it is considered genetically engineered. However, even if scions are shown to be free of transgenic DNA, since transgrafted crop products are new to consumption, it is likely that safety assessments will be required prior to their market release. They would potentially, however, be classified as a conventional and not genetically modified food in the United States.

Conversely, in the European Union, if biotechnology tools are used in the process of developing a crop, then they fall under EU legislation for genetically engineered crops. In this case, regardless of whether the final transgrafted crop product contains transgenic material (DNA, RNA or proteins) or not, it would be classified as genetically modified. For example, German authorities decided in 2010 that any grapes or wine produced from transgenic rootstocks must be labeled as genetically engineered (Heselmans 2011).

This international policy difference will put EU regulators in a difficult situation in the future, when importing crops harvested from transgrafted plants produced in the United States. How will they identify a nontransgenic crop product that has been developed using transgenic tools? How can they be certain that crops imported from countries such as the United States are not genetically engineered (by EU 


\section{References}

Aguero CB, Uratsu SL, Greve C, et al. 2005. Evaluation of tolerance to Pierce's disease and Botrytis in transgenic plants of Vitis vinifera L. expressing the pear PGIP gene. Mol Plant Pathol 6(1):43-51.

Astrid D. 2009. The dispersion and development of consumer preferences for genetically modified food - a meta-analysis. Ecol Econ 68(8-9):2182-92.

Atkinson RC, Beachy RN, Conway G, et al. 2003. Intellectual property rights. Public sector collaboration for agricultural IP management. Science 301(5630):174-5.

Bernard JC, Gifford K, Santora K, Bernard DJ. 2009. Willing ness to pay for foods with varying production traits and levels of genetically modified content. J Food Distribution Res 40(2):1-11.

[CDFA] California Department of Food and Agriculture. 2007. Pierce's Disease/Glassy Winged Sharpshooter Research Scientific Review Final Report, August. Pierce's Disease Research Scientific Advisory Panel.

COGEM. 2006. New Techniques in Biotechnology. COGEM Report CGM/061024-02. www.cogem.net/index cfm/en/publications/publicatie/new-techniques-inplant-biotechnology (accessed Oct. 21, 2011).

Escobar MA, Civerolo EL, Summerfelt KR, Dandekar AM. 2001. RNAi-mediated oncogene silencing confers resistance to crown gall tumorigenesis. PNAS USA 98(23):13437-42.Escobar MA, Leslie CA, McGranahan GH Dandekar AM. 2002. Silencing crown gall disease in walnut (Juglans regia L.). Plant Sci 163(3):591-7.

Gonsalves D. 2004. Virus-resistant transgenic papaya helps save Hawaiian industry. Cal Ag 58(2):92-3.
Graff GD, Wright BD, Bennett AB, Zilberman D. 2004. Access to intellectual property is a major obstacle to developing transgenic horticultural crops. Cal Ag 58(2):120-6.

Haroldsen V, Szczerba MW, Aktas H, et al. 2012. Mobility of transgenic nucleic acids and proteins within grafted rootstocks for agricultural improvement. Frontiers Plant Sci 3:39.

Heselmans M. 2011. Legal uncertainties obstruct breeders. Prophyta 52:16-21.

Huffman W, Rousu M. 2006. Consumer attitudes and market resistance to biotech products. In: Just RE, Alston JM, Zilberman D (eds.). Regulating Agricultural Biotechnol ogy: Economics and Policy. New York, NY: Springer Sci Bus Media. p 201-25.

James C. 2010. Global Status of Commercialized Biotech/ GM Crops: 2010. ISAAA Brief No 42. International Service for the Acquisition of Agri-Biotech Applications. Ithaca, NY

Kalaitzandonakes N, Alston JM, Bradford KJ. 2006. Compliance costs for regulatory approval of new biotech crops. In: Just RE, Alston JM, Zilberman D (eds.). Regulating Agricultural Biotechnology: Economics and Policy. New York, NY: Springer Sci Bus Media. p 37-57.

Lev-Yadun S, Sederoff R. 2001. Grafting for transgene containment. Nat Biotech 19(12):1104.

Lusk JL, House LO, Valli C, et al. 2004. Effect of information about benefits of biotechnology on consumer acceptance of genetically modified food: Evidence from experimental auctions in the United States, England, and France. Eur Rev Agric Econ 31(2):179-204.
Miller JK, Bradford KJ. 2010. The regulatory bottleneck for biotech specialty crops. Nat Biotechnol 28(10):1012-4.

Mou B, Scorza R (eds.). 2010. Transgenic Horticultural Crops: Challenges and Opportunities. Oxon, Eng.: Taylor Francis. $354 \mathrm{p}$.

Mulvaney DR, KrupnikTJ, Koffler KB. 2011. Transgenic rice evaluated for risks to marketability. Cal Ag 65(3):161-7.

Oerke EC, Dehne HW. 2004. Safeguarding production osses in major crops and the role of crop protection. Crop Prot 23(4):275-85.

[USDA APHIS] US Department of Agriculture Animal and Plant Health Inspection Service. 2010. USDA Announces Quarantine to Prevent Spread of Citrus Disease. www. aphis.usda.gov/newsroom/content/2010/06/citrus disease.shtml (accessed Jan. 4, 2012).

USDA APHIS. 2011. Biotechnology Permits, Notifications, and Petitions. Biotechnology Regulatory Services. www. aphis.usda.gov/biotechnology/brs_main.shtml (accessed Mar. 15, 2011).

[USDA ERS] USDA Economic Research Service. 2011 Value of Production for Selected Fruit and Tree Nuts, by State, 2007 to Date. www.ers.usda.gov/publications/fts/ Yearbook11/FTS2011.pdf (accessed Jan. 4, 2012).

[USDA NASS] USDA National Agricultural Statistics Service. 2011. Crop Value Summary 2011. http://usda. mannlib.cornell.edu/MannUsda/viewDocumentInfo. do?documentID=1050 (accessed Feb. 4, 2012). definitions) when testing may not differentiate between conventionally grown crops and those from transgrafted plants? While the European Union may elect to implement process monitoring of new technologies to ensure proper labeling, documenting every step of the production process and tracking the final products of transgrafted crops, it would be difficult to guarantee the genetically engineered status of imports from outside the European Union.

To address this difficulty, and assuming tests can be developed that easily and robustly detect the presence or absence of transgene elements in the final crop, a threshold limitation could be established. The EU threshold for allowable levels of "adventitious mixing" of genetically engineered seed into conventional seed is $0.9 \%$. The expectation for transgrafted crops, in particular first-generation transgrafts (see page 67), is that any transgenic DNA, mRNA, siRNA or protein would fall below the $0.9 \%$ level. While current EU legislation would likely need to be revised, it is possible that EU regulators would allow transgrafted fruit or nut products to enter the European Union, so long as transgenic material was below the $0.9 \%$ threshold. While strictly conjecture, at the least, this sort of threshold limitation should be included in discussions of alternatives to current regulatory requirements.

In the United States, transgrafting applications will likely be dealt with on a case-by-case basis as they are introduced into the regulatory process (C. Wood, USDA Biotechnology Regulatory Services, personal communication, September 2010). This would be in line with suggestions by the Dutch scientific advisory committee on genetically modified organisms (COGEM 2006). In anticipation of regulatory scrutiny, it will be important for scientists to gather experimental information determining to what degree transgenic elements move across the graft junction in different plant species and different types of coding and noncoding genetic constructs.

Unlike plant model systems, such as Arabidopsis sp., analyses of genetic material from fruit and nut crops tend to be compounded by high levels of phenolic compounds, polysaccharides and other secondary metabolites. Nevertheless, laboratory experiments have been carried out in walnut, grape and tomato regarding the mobility of transgenic elements, and the results are in the process of being published. This information should assist regulatory bodies in determining what portion of the scion, if any, should be regulated.

To illustrate these issues, imagine that a transgrafted orange is developed with transgenic siRNA in the rootstock that wards off nematodes. Tests on the scion leaf material do not reveal the presence of siRNA, but when the fruit is tested transgenic siRNA is detected. However, tests also show that after the oranges are harvested, the transgenic siRNA decreases over a short time to nondetectable levels. In the United States, after regulatory approval the oranges would not be required to be labeled as genetically engineered. If these sames oranges were exported to the European Union, siRNA would be undetectable in tests regardless of the transgraft, but under EU legislation they would be classified and labeled as genetically engineered. So unless the U.S. seller directly informs the importer that the oranges were grown with a transgraft, they would have no way of knowing since the siRNA is undetectable after picking. This example highlights the difficulties arising from policy differences, which could hamper the future commercialization of transgrafting technologies currently in the developmental pipeline. 